$\xi=\underline{E}$

\title{
Exergy analysis of combined cycle of gas turbine and solid oxide fuel cell in different compression ratios
}

\author{
Esmaeel Fatahian $^{1 *}$, Navid Tonekaboni ${ }^{1}$, Hossein Fatahian ${ }^{2}$ \\ ${ }^{1}$ PHD student, Department of Mechanical Engineering, Nour Branch, Islamic Azad University, Mazandaran, Iran \\ ${ }^{2}$ PHD student, Department of Mechanical Engineering, Shahroud Branch, Islamic Azad University, Semnan, Iran \\ *Corresponding author E-mail: esmaeelfatahian@gmail.com
}

\begin{abstract}
Due to the growing trend of energy consumption in the world uses of methods and new energy production systems with high efficiency and low emissions have been prioritized. Today, with the development of different systems of energy production, different techniques such as the use of solar energy, wind energy, fuel cells, micro turbines and diesel generators in cogeneration have been considered, each of these methods has its own advantages and disadvantages. Having a reliable energy generation system, inexpensive and availability the use of fuel cells as a major candidate has been introduced. Fuel cells converting chemical energy to electrical energy that today are one as a new technology in energy production are considered. In this paper fuel cell compression ratios 4, 4.1 and 4.2 at an ambient temperature of $298 \mathrm{~K}$ have been simulated and ultimately optimum ratio 4.1 for modeling has been selected. All components of cycle, including the stack of fuel cell, combustion chamber, air compressors, recuperator and gas turbine was evaluated from the viewpoint of exergy and exergy destruction rate was calculated by EES software.
\end{abstract}

Keywords: Solid Oxide Fuel Cell; Gas Turbine; Combined Cycle; Exergy; Compression Ratio.

\section{Introduction}

One of the important things that human beings from the beginning as a major challenge have faced with is finding new methods and high energy conversion efficiency of fuels into usable energy. One of the main ways that its technology has developed rapidly in recent decades, the use of fuel cells to provide electricity and heat simultaneously is by electrochemical method. In this method, that is to say it can be considered a reverse electrolysis, chemical energy stored in fossil fuels are extracted without combustion. These systems in comparison to other methods received a great deal of efficiency and produced little pollution. Since fuel cells generate electricity through the chemical will be better than combustion, they do not have limitations of the laws of thermodynamics that the conventional power plant has had. Therefore, the fuel cell will have more efficient in producing energy from a fuel. Also with more increasing system efficiency waste heat from some cells can be inhibited. One of the most important types of fuel cells is solid oxide fuel cell which uses non-porous and extremely hard ceramic as the electrolyte. High operating temperature of the cell causes the output to be used as an energy source to launch gas micro turbine. Theoretical investigations on this type of hybrid system for the first time have been done in 1970 by the American company Zymens-Westinghouse. [1] In this study, the gas turbine is used as a hybrid system. Thermodynamic and mathematical models have been developed and educed by several research groups that the most important groups can be noted such as Masardo et al. in 1997 and tried to thermodynamic simulation and modeling of fuel cell and an article under the same title was published in 1998. [2] This modeling can be mentioned as one of the first simulation of thermodynamic modeling of fuel cells. Campanari et al. have done thermodynamic analysis of fuel cell in the same year with the help of rankine cycle and have seen the increase of quantitative combined efficiency of this cycle. [3] Efforts have been started in 1998 and have continued until now, by different considering and simulating, efficiency of combined cycle fuel cell and exergy efficiency of this cycle increased. Additional past work on modeling and performance analysis of hybrid systems was documented by Costamagna et al. [4], Yang et al. [5] and Araki et al. [6]. Most of these past studies emphasize the numerical modeling of SOFC performance. A recent study by Granovskii et al. (2007) has included the exergy analyses for two SOFC-gas turbine systems to determine their efficiencies and capabilities of generating power at different rates of oxygen transport through the SOFC electrolyte. [7] In our country, the need to reduce air pollution and the environment and efficient use of energy resources, it doubles the attention to this technology. Researches in the field of new energy sources, particularly fuel cells have been growing in our country . In this paper, different compression ratios of $4,4.1$ and 4.2 were studied to determine the appropriate ratio to increase efficiency. All models are at ambient temperature despite previous attempts were have been at a temperature of 288 Kelvin.

\section{System description}

In this paper, combined system of solid oxide fuel cell and gas turbine has been studied.

We are studying the combined system consists of six sections: [8]

1) air compressor.

2) Recuperator.

3) Stack of solid oxide fuel cell with internal reforming.

4) Combustion chamber.

5) Gas turbines driving compressors.

6) Gas turbine power generator.

Copyright () 2016 Esmaeel Fatahian et al. This is an open access article distributed under the Creative Commons Attribution License, which permits unrestricted use, distribution, and reproduction in any medium, provided the original work is properly cited. 


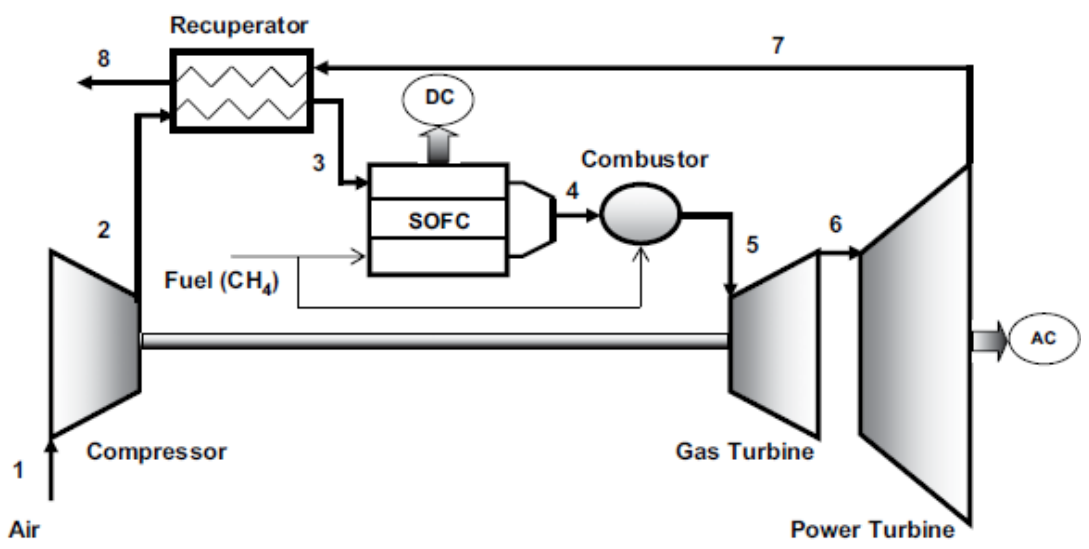

Fig. 1: Schematic Combined Cycle of Solid Oxide Fuel Cell and Gas Turbine [8].

The overall system has been shown schematically in Fig.1. Next, the points 1 to 8 are the points that will be examined from the point of view of thermodynamics. Both the combustion chamber and solid oxide fuel cell use pure methane fuel.

In this system, the air is imported to compressor from point 1 and the compressed air is exiting from point 2 . For a gas turbine power plant, preheating the air by a recuperator heat by hot exhaust gases from the gas turbines, increases thermal efficiency of the entire system. Compressed air enters into recuperator and heated to a temperature of point 3 . Then air enters the cathode side of the stack of fuel cell to participate in the electrochemical reaction. On the other hand, fuel enters to the fuel cell anodes. After an electrochemical process, DC power is generated. Also, due to internal irreversibility fuel cell (often ohmic resistance) during the process, heat can be obtained. And causes the temperature of the product has increased to point 4 and enters into the combustion chamber and with the other fuel from the combustion chamber at point 5 enters into the turbine. And after circulating the compressor, at point 6 enters into the power turbine and generates power. The heat of exhaust gases from the power turbine, are used in recuperator at point 7 and after heating the intake air to the fuel cell, and finally at the point 8 the exhaust gasses enter into the environment.

\section{Thermodynamic analysis of the system}

Thermodynamic performance of each of sections is considered here. For thermodynamic modeling we assume that the working fluid that shown in all points is ideal gas. Changes in Kinetic and potential energy are assuming zero and also assuming the steady flow for first and second law of thermodynamics for the entire cycle are examined.

\subsection{Compressor}

Intake air to the compressor with molar combination of $0 / 21$ oxygen and 0/79 nitrogen, is the ambient air.

Isentropic efficiency (Constant entropy) of the compressor is determined as follows:

$$
\eta_{\mathrm{c}}=w_{\mathrm{cs}} / w_{\mathrm{ca}}=\left(\mathrm{h}_{2 \mathrm{~s}}-\mathrm{h}_{1}\right) /\left(\mathrm{h}_{2}-\mathrm{h}_{1}\right)
$$

In the output of compressor, the ideal temperature of fluid can be obtained using the following equation:

$$
\mathrm{T}_{2 \mathrm{~s}} / \mathrm{T}_{1}=\left(\mathrm{P}_{2} / \mathrm{P}_{1}\right)^{(\gamma-1) / \gamma}
$$

The work needed for the compressor to produce the desired compression ratio, by applying an energy balance for the system can be obtained using the following equation:

$W_{\dot{\mathrm{C}}}=\dot{\mathrm{m}}_{1}\left(\mathrm{~h}_{2}-\mathrm{h}_{1}\right)$
Given the input and output condition, the rate of entropy production during the compression process is calculated as follows:

$\dot{\mathrm{S}}_{\mathrm{genc}}=\dot{\mathrm{m}}_{1}\left(\mathrm{~s}_{2}-\mathrm{s}_{1}\right)$

\subsection{Recuperator}

Recuperator efficiency is calculated as follows: [9]

$\varepsilon_{\text {Recup }}=\left(\mathrm{T}_{3}-\mathrm{T}_{2}\right) /\left(\mathrm{T}_{7}-\mathrm{T}_{2}\right)$

Outlet temperature of cycles, using the energy balance equation is calculated as follows:

$\dot{\mathrm{m}}_{2}=\left(\mathrm{h}_{3}-\mathrm{h}_{2}\right)=\mathrm{m}_{7}\left(\mathrm{~h}_{7}-\mathrm{h}_{8}\right)$

Entropy balance equation for recuperator is calculated as follows:

$\dot{\mathrm{m}}_{2} \mathrm{~s}_{2}+\dot{\mathrm{m}}_{7} \mathrm{~s}_{7}-\dot{\mathrm{m}}_{3} \mathrm{~s}_{3}-\dot{\mathrm{m}}_{8} \mathrm{~s}_{8}+\mathrm{S}_{\text {gen, } \mathrm{c}}=0$

According to the conservation of mass, the rate of entropy production in recuperator as follows:

$\mathrm{S}_{\text {gen.Recup }}=\mathrm{m}_{2}\left(\mathrm{~s}_{3}-\mathrm{S}_{2}\right)-\mathrm{m}_{7}\left(\mathrm{~s}_{7}-\mathrm{s}_{8}\right)$

\subsection{Solid oxide fuel cell}

Fuel used in the fuel cell is methane $(\mathrm{CH} 4)$ with low heating value equal to $50050 \mathrm{kj} / \mathrm{kg}$. [8]

The following electrochemical reaction in the fuel cell is happening .[8]

$\mathrm{CH}_{4}+2 \mathrm{O}_{2}=\mathrm{CO}_{2}+2 \mathrm{H}_{2} \mathrm{O}$

To calculate the fuel cell voltage of Nernst's famous equation that follows, we use:

$\mathrm{E}=\mathrm{E}^{0}-\mathrm{RT} / \mathrm{n}_{\mathrm{e}} \mathrm{F} \ln \left(\mathrm{P}_{\mathrm{H} 2 \mathrm{O}} / \mathrm{P}_{\mathrm{H} 2} \mathrm{P}_{\mathrm{O} 2}{ }^{1 / 2}\right)$

(E) is defined as ideal voltage of fuel cell in temperature and different partial pressures of reactants and products and $\left(\mathrm{E}_{0}\right)$ is defined as reversible fuel cell voltage at standard conditions (298.15k and 1 Bar).

The current density $(\mathrm{J})$ is defined as the production per unit area of active fuel cell, electric power (DC) produced by the fuel cell can be expressed by this equation:

$$
W_{\mathrm{FC}, \mathrm{dc}}=\mathrm{V}_{\mathrm{c}} \mathbf{J}_{\mathrm{Ac}}
$$

Voltage of cell: The voltage difference between the open circuit voltage obtained from the Nernst equation and it is the lost voltage of cells. 
$\mathrm{V}_{\mathrm{c}}=\mathrm{E}-\Delta \mathrm{v}_{\text {loss }}$

$\Delta \mathrm{V}_{\text {loss }}=\mathrm{V}_{\text {act }}+\mathrm{V}_{\text {ohm }}+\mathrm{V}_{\text {conc }}$

As a result, irreversibility, the amount of heat produced inside the cell. The following equation was used to determine the rate of heat production in cells:

$\mathrm{Q}_{\mathrm{gen}, \mathrm{FC}}=\mathrm{I} \Delta \mathrm{V}_{\text {loss }}=\mathrm{J} \mathrm{A}_{\mathrm{c}}(\mathrm{E}-\mathrm{Vc}) * 10^{-6}[\mathrm{kw}]$

The oxygen that is participated in overall reaction is obtained from the air. The amount of intake air to the fuel cell is higher than stoichiometric amount, (Generally, more than twice). The following equation was used to indicate mass flow rate: [8]

Air $\mathrm{usage}=3.57 \times 10^{-7} \times \lambda \times \mathrm{W}_{\mathrm{fc}, \mathrm{dc}} / \mathrm{Vc}[\mathrm{kg} / \mathrm{s}]$

Schematic flow of input and output solid oxide fuel cell can be seen in Figure 1. Law of mass balance for the SOFC is as follows:

$\dot{\mathrm{m}}_{3}+\dot{\mathrm{m}}_{\text {fuel, } \mathrm{FC}}=\dot{\mathrm{m}}_{4}=\dot{\mathrm{m}}_{3}+\mathrm{m}_{\text {fuel, } \mathrm{FC}} \times \mathrm{U}_{\mathrm{f}}+\dot{\mathrm{m}}_{\text {fuel, FC }} \times\left(1-\mathrm{U}_{\mathrm{f}}\right)$

$\left(U_{f}\right)$ is coefficient of fuel consumption. Unreacted mass flow that is exited from the fuel cell by using the first law of thermodynamics for solid oxide fuel cells and with assumption of an adiabatic process is calculated as follows:

$\dot{\mathrm{m}}_{3} \mathrm{~h}_{3}+\dot{\mathrm{m}}_{\text {fuel, FC }} \times \mathrm{U}_{\mathrm{f}} \times \mathrm{LHF}+\dot{\mathrm{m}}_{\text {fuel, FC }} \times\left(1-\mathrm{U}_{\mathrm{f}}\right) \mathrm{h}_{\text {fuel, in }}-\dot{\mathrm{m}}_{4} \mathrm{~h}_{4}=0$ (16)

Also the solid oxide fuel cell entropy equation can be expressed as follows:

$\dot{\mathrm{m}}_{3} \mathrm{~S}_{3}+(\dot{\mathrm{m} S})_{\text {fuel, FC }}-\dot{\mathrm{m}}_{4} \mathrm{~S}_{4}+\mathrm{S}_{\mathrm{gen}, \mathrm{FC}}=0$

\subsection{Combustion chamber}

Exhaust gases from the solid oxide fuel cell for heating more are entering into the combustion chamber. We should emphasize that methane that is not reacted in the fuel cell with exhaust gas from fuel cell enter into the combustion chamber, where it burns completely.

First Law of Thermodynamics for the combustion chamber can be written as follows:

$\left(\dot{\mathrm{m}}_{3}+\dot{\mathrm{m}}_{\text {fuel }}, \mathrm{FC} \mathrm{U}_{\mathrm{f}}\right) \mathrm{h}_{4}+\dot{\mathrm{Q}}_{\mathrm{comb}}-\dot{\mathrm{m}}_{5} \mathrm{~h}_{5}-\dot{\mathrm{Q}}_{\text {LOSS }}=0$

Entropy balance equation can be written as follows for the combustion chamber and using entropy production rate is obtained in the combustion chamber:

$\dot{\mathrm{m}}_{4} \mathrm{~S}_{4}+(\dot{\mathrm{mSS}})_{\text {fuel, comb }}+\left(\dot{\mathrm{Q}}_{\mathrm{comb}} / \mathrm{T}_{\text {comb }}\right)+\dot{\mathrm{S}}_{\mathrm{gen}}, \mathrm{Comb}-\dot{\mathrm{m}}_{5} \mathrm{~S}_{5}-$

$\left(\mathrm{Q}_{\text {loss }} / \mathrm{T}_{\text {surr }}\right)=0$

(19)

\subsection{Gas turbine}

Duty for providing the work for compressor is the gas turbine responsibility and should be conform in design with gas turbine By knowing the internal temperature of turbine, the outlet temperature of turbine can be determined with determination of isentropic efficiency:

$\eta_{\mathrm{GT}}=W_{\mathrm{GTa}} / \mathrm{W}_{\mathrm{GTs}}=\left(\mathrm{h}_{5}-\mathrm{h}_{6}\right) /\left(\mathrm{h}_{5}-\mathrm{h}_{6 \mathrm{~s}}\right)$

The rate of entropy production in the turbine is as follows:

$\mathrm{S}_{\mathrm{gen}, \mathrm{GT}}=\dot{\mathrm{m}}_{5}\left(\mathrm{~S}_{6}-\mathrm{S}_{5}\right)$

\subsection{Power turbine}

Power turbine has the task of power generation. The first law of thermodynamic can be written as follows:

$\dot{\mathrm{m}}_{6} \mathrm{~h}_{6}-\dot{\mathrm{m}}_{7} \mathrm{~h}_{7}+\dot{W}_{\mathrm{PT}}=0$

Also entropy balance equation for turbine can be written as follows:

$\dot{\mathrm{m}}_{6} \mathrm{~S}_{6}-\dot{\mathrm{m}}_{7} \mathrm{~S}_{7}+\mathrm{S}_{\mathrm{gen}}, \mathrm{PT}=0$

The entropy production rate is obtained from the following equation:

$\mathrm{S}_{\mathrm{gen}, \mathrm{PT}}=\dot{\mathrm{m}}_{6}\left(\mathrm{~S}_{7}-\mathrm{S}_{6}\right)$

\section{The ultimate equilibrium equations for combine cycle of solid oxide fuel cell and gas turbine}

Energy conservation equation for the combined system is as follows: [10]

$\dot{\mathrm{m}}_{1} \mathrm{~h}_{1}+\dot{\mathrm{m}}_{\text {fuel, } \mathrm{FC}} \times \mathrm{U}_{\mathrm{f}} \times \mathrm{LHF}_{\mathrm{CH} 4} \mathrm{Q}_{\mathrm{comb}}-\dot{\mathrm{m}}_{8} \mathrm{~h}_{8}-\mathrm{Q}_{\mathrm{LOSS}}-W_{\mathrm{FCdc}}-W_{\mathrm{PT}}$ $=0$

The ultimate thermal efficiency for gas turbine and solid oxide fuel cell power plant is the ratio of the rate of work of net output to the total rate of input energy to the system is determined:

$\eta_{\text {th, cyc }}=\dot{W}_{\text {net }} / \mathrm{Q}_{\text {tot }}$

Wnet is the net power generated by the cycle which is defined as follows:

$\dot{W}_{\mathrm{net}}=\dot{W}_{\mathrm{T}, \mathrm{Gen}}+\dot{W}_{\mathrm{Fc}, \mathrm{Ac}}$

$\dot{W}_{\mathrm{Fc}, \mathrm{Ac}}=\dot{W}_{\mathrm{Fc}, \mathrm{dc}} \times \eta_{\text {invert }}$

$\dot{W}_{\mathrm{T}, \mathrm{Gen}}=\eta_{\mathrm{Gen}} \dot{W}_{\mathrm{T}}$

The rate of entropy production in the system is the total entropy which is produced in all components:

$\mathrm{S}_{\mathrm{cyc}}=\dot{\mathrm{m}}_{8} \mathrm{~S}_{8}-\dot{\mathrm{m}}_{1} \mathrm{~S}_{1}-(\dot{\mathrm{m} S})_{\text {fuel }}-\mathrm{Q}_{\text {comb }} / \mathrm{T}_{\text {comb }}+\mathrm{Q}_{\text {Loss } /} \mathrm{T}_{\text {sink }}$

The Specifications of combined cycle of gas turbines and solid oxide fuel cells are listed below:

Table 1: Operating Conditions of Combined Cycle Cycle gas turbine

0.79 Compressor Efficiency (\%)

$0.86 \quad$ Turbine Efficiency $(\%)$

0.90 Gas turbine power efficiency (\%)

0.75 Recuperator effect coefficient

0.97 Combustion chamber efficiency (\%)

0.93 Generator efficiency (\%)

4.1 The compression ratio of compressor

1163 The turbine inlet temperature (K)

5.12 Air mass flow rate $(\mathrm{kg} / \mathrm{s})$

$0.0167 \quad$ Fuel mass flow $(\mathrm{kg} / \mathrm{s})$

Solid oxide fuel cell

$0.82 \quad$ Fuel consumption coefficient

$0.3 \quad$ Operating temperature

$1190.12 \quad$ Current density

0.86 Current transformer efficiency

$498 \quad$ Cell area

$0.046 \quad$ Fuel mass flow

$347 \quad$ Number of cells of fuel cell

23.18 Electricity for electrolysis (V) 


\begin{tabular}{ll}
54.67 & Electrolysis efficiency $(\%)$ \\
Pressure drop & \\
4 & Both side of recuperator $(\%)$ \\
4 & Fuel cell stack (\%) \\
4 & Combustion chamber $(\%)$ \\
Ambient conditions \\
298 & Temperature (K) \\
1 & Pressure (atm) \\
50 & Humidity (\%) \\
\hline
\end{tabular}

\section{Results}

All the equations for exergy modeling have entered in EES software and the results of the cycle (Table 1) in the form of graphs are shown in this section.

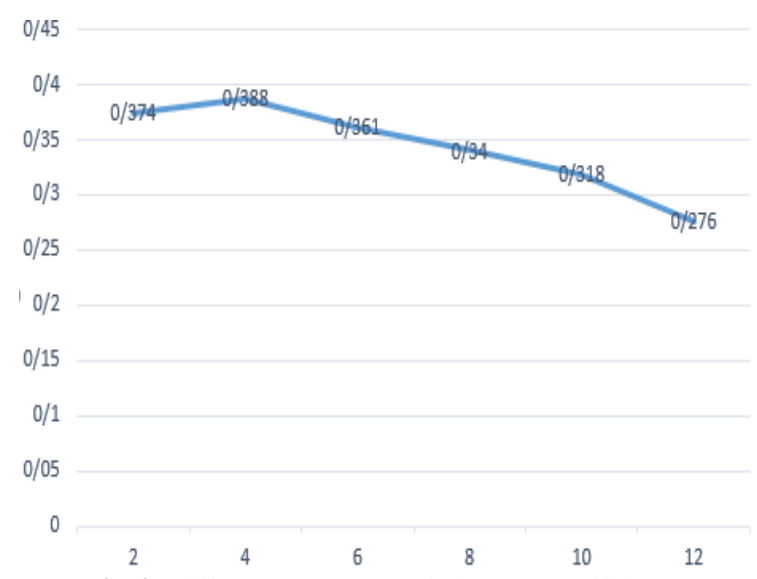

Fig. 2: Different Pressures Ratio in Exergy Efficiency.

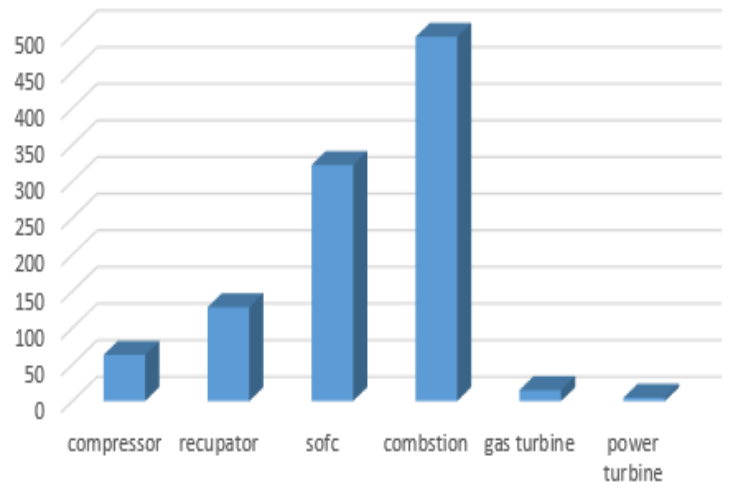

Fig. 3: Exergy Destruction Rate of Each Component.

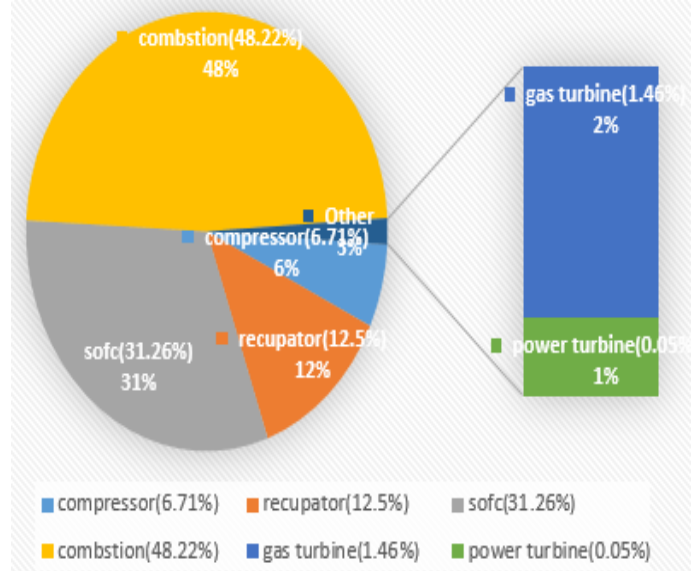

Fig. 4: Exergy Destruction Percentage for Each Components of the Cycle.
Table 2: Exergy Destruction Rate of Each Component of System (KW)

\begin{tabular}{ll}
\hline 63.12 & Compressor \\
\hline 128.45 & Recuperator \\
322.44 & SOFC \\
497.34 & Combustion Chamber \\
15.11 & Gas turbine \\
4.72 & Power turbine \\
1031.28 & The entire system \\
\hline
\end{tabular}

\section{Conclusion}

In this study simulation was done at ambient conditions, pure methane as a fuel is selected in the fuel cell and ambient air at a temperature of $298 \mathrm{~K}$ with molar ratio of oxygen $21 / 0$ and nitrogen 79/0 is considered. fuel cell in compression ratios 4, 4.1 and 4.2 of compressor and at an ambient temperature have been simulated and it was observed that although in previous simulations the optimal compression ratio of compressor was 4 at a temperature of $288 \mathrm{~K}$ but at a temperature of $298 \mathrm{~K}$ the compression ratio 4,1 is the optimum ratio, and then we saw a decrease in efficiency. Exergy destruction rate of components of entire system was calculated by the EES software. In this analysis, compressor efficiency is considered $79 \%$ that compressors usually have efficiency about $75 \%$ to $85 \%$ but mainly they are in the range of $78 \%$ to $80 \%$. We raised the compression ratio to 4.2 and it was observed that the best ratio is at 4.1 and then efficiency is decreased, these results obtained after three-time calculation in compression ratios 4 and 4.1 and 4.2. Thermal efficiency for fuel cells is usually obtained from $55 \%$ to $80 \%$. In this study, the efficiency achieved $61.01 \%$ and it was observed that in compression ratio of 4.1 and an ambient temperature of $298 \mathrm{~K}$ we have reached to this efficiency. The most exergy destroyed rate is in the combustion chamber at a rate of $497.34 \mathrm{KW}$ that are $48.22 \%$ of the total destruction of exergy of the system, this is due to high temperatures of combustion chamber and high rates of heat transfer with the environment. Then solid oxide fuel cell with the rate of $322.44 \mathrm{KW}$ which included $31.24 \%$ of exergy destruction is the second factor of exergy destruction. The lowest rate of exergy destruction of system is in power turbine with $4.72 \mathrm{KW}$ which is included only $0.05 \%$ of the total exergy destruction of the system, this amount is negligible and can be ignored and it is better to be used than optimization of other parts of the system in order to reduce exergy destruction of system. In order to improve efficiency, rate of exergy destruction in the combustion chamber and solid oxide fuel cell should be reduced. The most factors of exergy destruction are the differences of temperatures and pressures drop. Exergy efficiency of the cycles in compression pressure of 4 is equal to $51.2 \%$. In pressure compression of 4.1 , this amount is equal to $52.89 \%$ and in pressure compression of 4.2 the efficiency is reduced and reached to the amount of $51.63 \%$. From the above calculations it can be concluded that the appropriate compression ratio at temperature of $298 \mathrm{~K}$ (ambient condition) is 4.1 which is increased the exergy efficiency of system about $2 \%$.

\section{References}

[1] Veyo, Stephen E., et al. "Tubular Solid Oxide Fuel Cell/Gas Turbine Hybrid Cycle Power Systems-Status." ASME Turbo Expo 2000: Power for Land, Sea, and Air. American Society of Mechanical Engineers, 2000. http://dx.doi.org/10.1115/2000-gt-0550.

[2] Massardo, A. F., and F. Lubelli. "Internal reforming solid oxide fuel cell-gas turbine combined cycles (IRSOFC-GT): Part a-Cell model and cycle thermodynamic analysis." ASME 1998 International Gas Turbine and Aeroengine Congress and Exhibition. American Society of Mechanical Engineers, 1998. http://dx.doi.org/10.1115/98-gt-577.

[3] Campanari, S., and E. Macchi. "Thermodynamic analysis of advanced power cycles based upon solid oxide fuel cells, gas turbines and rankine bottoming cycles." ASME 1998 International Gas Turbine and Aeroengine Congress and Exhibition. American Society of Mechanical Engineers, 1998. http://dx.doi.org/10.1115/98-gt-585. 
[4] Costamagna, P., L. Magistri, and A. F. Massardo. "Design and partload performance of a hybrid system based on a solid oxide fuel cell reactor and a micro gas turbine." Journal of Power Sources 96.2 (2001): 352-368. http://dx.doi.org/10.1016/S0378-7753(00)00668-6.

[5] Yang, W. J., et al. "Design performance analysis of pressurized solid oxide fuel cell/gas turbine hybrid systems considering temperature constraints." Journal of Power Sources 160.1 (2006): 462-473. http://dx.doi.org/10.1016/j.jpowsour.2006.01.018.

[6] Araki, Takuto, et al. "Cycle analysis of planar SOFC power generation with serial connection of low and high temperature SOFCs." Journal of Power Sources 158.1 (2006): 52-59. http://dx.doi.org/10.1016/j.jpowsour.2005.09.003.

[7] Granovskii, Mikhail, Ibrahim Dincer, and Marc A. Rosen. "Performance comparison of two combined SOFC-gas turbine systems." Journal of Power Sources $165.1 \quad$ (2007): 307-314. http://dx.doi.org/10.1016/j.jpowsour.2006.11.069.

[8] Haseli, Y., I. Dincer, and G. F. Naterer. "Thermodynamic modeling of a gas turbine cycle combined with a solid oxide fuel cell." International Journal of Hydrogen Energy 33.20 (2008): 5811-5822. http://dx.doi.org/10.1016/j.ijhydene.2008.05.036

[9] Cohen, Henry, et al., Gas turbine theory, (1987).

[10] Shapiro H.N., Moran M.J, Fundamental of Engineering Thermodynamics, John Wiley \& Sons. Motahar, S, (2006). 